\title{
Studies on Native Isolates of Fungal and Bacterial Bio-agents against Collar Rot of Chickpea
}

\author{
Jhumishree Meher ${ }^{1}$, Punam Kashyap ${ }^{2}$, Siddharth Shankar Sonkar ${ }^{2}$, \\ S.N. Singh ${ }^{2}$ and Sanam Kumari ${ }^{3 *}$ \\ ${ }^{1}$ Department of Mycology and Plant Pathology, Institute of Agricultural Sciences, Banaras \\ Hindu University, Varanasi, Uttar Pradesh, India \\ ${ }^{2}$ Department of Plant Pathology, Jawaharlal Nehru Krishi Viswa Vidyalaya, Jabalpur, \\ Madhya Pradesh, India \\ ${ }^{3}$ Department of Plant Physiology, Institute of Agricultural Sciences, Banaras Hindu \\ University, Varanasi, Uttar Pradesh, India \\ *Corresponding author
}

\section{A B S T R A C T}

\begin{tabular}{|c|c|}
\hline & Sclerotium rolfsii Sacc, [teleomorph: Athelia rolfsii (Curzi)] causing collar rot of chickpea, \\
\hline Keywords & yield loss is recorded annually according to severity of the disease. It is more serious at \\
\hline $\begin{array}{l}\text { Chickpea, } \\
\text { Trichoderma, } \\
\text { Sclerotium rolfsii, } \\
\text { Pseudomonas } \\
\text { fluorescence, Collar } \\
\text { rot }\end{array}$ & $\begin{array}{l}\text { was undertaken to find out bio-efficacy of twenty native isolates of Trichoderma spp. } \\
\text { isolated from rhizospheric zone of eight different crops from different locations of } \\
\text { Jabalpur by using serial dilution method against Sclerotium rolfsii and their effects on } \\
\text { growth parameters of chickpea plant. In vitro screening of isolates (20) of Trichoderma } \\
\text { spp. against Sclerotium rolfsii was done by dual culture technique with } 87.41 \text { and } 39.78 \%\end{array}$ \\
\hline Article Info & $\begin{array}{l}\text { of maximum and minimum per cent zone inhibition recorded with T- } 20 \text { and } \mathrm{T}-7 \text { isolate. } \\
\text { On the basis of cultural and morphological characters best eight isolates; one from each }\end{array}$ \\
\hline $\begin{array}{l}\text { Accepted: } \\
\text { 04 December } 2017 \\
\text { Available Online: } \\
\text { 10 January } 2018\end{array}$ & $\begin{array}{l}\text { host were selected for further studies in polyhouse. Tr- } 7 \text { was found to be most effective } \\
\text { with minimum seedling mortality of } 6.67 \% \text {. Soil inoculation was found more effective as } \\
\text { compared to seed treatment in controlling seed rotting as well as seedling mortality. In } \\
\text { combination treatments some isolates of Trichoderma spp. were found to be synergistic }\end{array}$ \\
\hline & $\begin{array}{l}(\operatorname{Tr}-2, \operatorname{Tr}-4, \operatorname{Tr}-6, \operatorname{Tr}-7 \text { and } \operatorname{Tr}-8) \text { whereas, some exhibiting antagonistic effect }(\operatorname{Tr}-1, \operatorname{Tr}- \\
3 \text { and } \operatorname{Tr}-5) \text { with Pseudomonas fluorescence. }\end{array}$ \\
\hline
\end{tabular}

\section{Introduction}

Persoon (1794) was the first scientist to propose Trichodermaas a genus over two hundred years ago back. It was described as mealy powder enclosed by a hairy covering.
Thakur and Norris (1928) from Madras isolated Trichoderma in India first time. It is a potent fungal bio-control agent against a wide range of plant pathogens. Especially, for the management of soil borne plant pathogens Trichoderma spp. was reported as important 
biological control agents (Upadhyay and Mukhopadhyay, 1986, Kumar et al., 2012andJabbar et al., 2014). It was reported that Trichoderma spp. involves wide range of key characteristic mechanisms for disease control i.e, Mycoparasitism and hyphallysis, antibiosis, competition for nutrients and space and also promotion of plant growth (Rudresh et al., 2005; Jash et al., 2007 and Swathi et al., 2015). Enhance plant growth response and productivity was induced with application of Trichoderma species and other root colonizing fungi reported in many crops such as beans, cucumber, pepper, Carnation, maize and wheat (Balasubramanian, 2003). Collar rotis a devastating soil-borne disease of chickpea caused by fungus Sclerotium rolfsii Sacc, [teleomorph: Athelia rolfsii (Curzi)], causing heavy economic losses (Kokub et al., 2007). Wherever chickpea is grownall over the world it is almost reported everywhere and caused 10 to 30 per cent yield loss annually according to severity of the disease (Nene et al., 1984).

Several control measures have been adopted for control of $S$. rolfsii by many scientists which includes biological control (Pandey and Chaube, 2004), cultural control (Blum and Rodriguez-kabana, 2006 and Pinheiro et al., 2010), and chemical control (Paula et al., 2011). Over conventional fungicides, biological control of plant pathogens has a number of advantages, as fungicides features only a temporary effect and require repeated applications during the growing period of crop while, the biological control agents are able to establish themselves, colonize and reproduce in the ecosystem (Melo and Faull, 2000).

\section{Materials and Methods}

Isolation Purification and identification of Trichoderma spp. and test pathogen

For isolation of different isolates of Trichoderma spp., soil samples were collected from different locations of Jabalpur. The soil samples were collected with the help of a soil augur up to a depth of $15-20 \mathrm{~cm}$ from rhizospheric zone individual plants, well dried and were stored in refrigerator $4 \pm 1^{\circ} \mathrm{C}$ until further use. Soil sample of $5 \mathrm{~g}$ weight was weighed and placed in a beaker containing 95 $\mathrm{ml}$ of sterile distilled water. After shaking thoroughly, it was allowed to stand for a few minutes. Then serial dilution was made up to $10^{-4}$ dilution and $1 \mathrm{ml}$ was drawn from each dilution and spread over the PDA plate and incubated at $28 \pm 1{ }^{\circ} \mathrm{C}$. The plates were monitored regularly for the development of colonies. The Trichoderma isolates were subjected to sub-culturing on PDA medium for purification. Sub-culturing was done. These Petri plates were incubated at $28 \pm 1{ }^{0} \mathrm{C}$ for seven days with periodic observation for development of colonies of Trichoderma spp. The colonies of Trichoderma were identified by key based on branching of conidiophores, shape of phialides, emergence of phialides and spore characters (Gams and Bisset, 2002).Isolation of Sclerotium rolfsii was done from infected collar and upper root portion. Surface sterilized was done with $0.1 \%$ of $\mathrm{HgCl}_{2}$ solution for $1 \mathrm{~min}$, then aseptically transferred to Petri plates containing the sterilized PDA medium and incubated at $28 \pm 1$ ${ }^{\circ} \mathrm{C}$. By single sclerotia method under aseptic conditions pure culture was maintained (Pandey et al., 2010).

\section{Screening of antagonistic potential of Trichoderma spp. in vitro}

Screening of twenty one isolates of Trichoderma spp. for their antagonistic potential in vitro against $S$. rolfsii was done by using dual culture method. Per cent inhibition of the pathogen over control was calculated by adopting the formula from Rudresh et al., (2005).

$\mathrm{I}(\%)=(\mathrm{C}-\mathrm{T}) / \mathrm{C} \times 100$ 
Where, $\mathrm{I}=$ Percent growth inhibition, $\mathrm{C}=$ Growth in control (monoculture), $\mathrm{T}=$ Growth in treatment (dual culture)

Evaluation of bio-efficacy of Trichoderma spp. and Pseudomonas fluorescens against S. rolfsii in vivo

Both the pathogen and antagonist were multiplied on sorghum grains. Sorghum grains were pre-soaked in 2 per cent sucrose solution overnight, drained and boiled in fresh water for 30 minutes and drained again. This was transferred into $1000 \mathrm{ml}$ flasks @ $400 \mathrm{~g}$ and autoclaved at $15 \mathrm{lb}$ psi $\left(121.6{ }^{0} \mathrm{C}\right)$ for 20 minutes.

The flasks were allowed to cool at room temperature and inoculated with five $\mathrm{mm}$ discs of 3 to 4 days old culture of $S$. rolfsii grown on PDA. Seven discs per flask were added and flasks were incubated for three weeks at $28 \pm$ $1{ }^{0} \mathrm{C}$. Pot culture studies were conducted to evaluate efficacy of Trichoderma in vivo. By using two different application methodologies, i.e. seed treatment with $5 \mathrm{~g} / \mathrm{kg}$ seed and soil application with $10 \mathrm{~g} / \mathrm{kg}$ soil were used to assess the bio-control potential of Trichoderma isolates alone and in combination with Pseudomonas fluorescens in decreasing the collar rot of chickpea caused by S. rolfsii and also their effects on growth parameters of chickpea plant. Chickpea seed were sown@5 seed/pot and were watered time to time. Percent germination was recorded 10 days after sowing and final count after 30 days of sowing. Height $(\mathrm{cm})$, dry weight and fresh weight (gm) were recorded to calculate vigour index mass, vigour index percentage and seedling mortality up to 30 days by using following formulae given by (Kharbet al., 1994) ;

Total number of seed germinated Germination $(\%)=$ $\times 100$

Total number of seed sown
Number of diseased plants

$\begin{aligned} \text { Mortality }(\%)= & ----------------------\times 100 \\ & \text { Total number of seedlings }\end{aligned}$

\section{Results and Discussion}

Twenty isolates of Trichoderma spp. were collected from different locations of Jabalpur from rhizospheric zone of eight different crops viz., Rice, Red gram, Okra, Soybean, Black gram, Green gram, Neem and Sesame (Table 1). These were designated with symbol $\mathrm{T}-1$, T- 2, T- 3 up to T- 20 according to the order they were collected.Online interactive keys of Samuels et al., (2002) used for identification of the potential isolates of Trichoderma spp. based on the colony appearance and pigmentation, the presence, growth rate and branching patterns of conidiophores.

Radial growth rate of different twenty isolates of Trichoderma spp. was also recorded on PDA at different incubation periods at $28 \pm 1{ }^{\circ} \mathrm{C}$. In vitro screening of isolates of Trichoderma spp. against Sclerotium rolfsii done by Dual culture technique (Table 1). Maximum per cent zone inhibition of 87.41per cent recorded with T- 20 isolate, followed by $85,77.3,71.11,69.11,61.85$ and 60.11 per cent with isolates T- $10, \mathrm{~T}-1, \mathrm{~T}-15, \mathrm{~T}-2, \mathrm{~T}-$ 17 and $\mathrm{T}-4$ respectively against 0 per cent in control. Whereas, minimum per cent zone inhibition of 39.78 per cent recorded with T- 7 isolate, followed by 49.82 and 52.22 per cent in T- 13 and in T- 3 isolate respectively. Almost isolates were found to have significant variation among them, whereas differences among T- 5, T- 6, T- 8, T- 9, T- 12, T- 16, T18 and $\mathrm{T}-19$ isolates were found at par. T- 3, T- 2, T- 17, T- 14, T- 10, T- 20, T- 15 and T5 were selected from each crop i.e., Red gram, Rice, Soybean, Sesame, Green gram, Black gram, Neem and Okra plant rhizosphere respectively and were re-designated as $\mathrm{T}-1$ as Tr- 1 , T- 2 as Tr- 2, T- 17 as Tr- 3, T- 14 as Tr- 4, T- 10 as Tr- 5, T- 20 as Tr- 6, T- 15 as 
Tr- 7 and T- 5 as Tr- 8 (Plate- 1) and were used for further studies.

Efficacy isolates of Trichoderma spp. against collar rot incidence of chickpea in Cvs JG 14 and JG 24

\section{On seed treatment}

It was observed that, on seed seed treatment significant increase in germination percentage up to 100 per cent was recorded with $\mathrm{Tr}-2$, Tr- 6 and Tr- 7 over control $(66.67 \%)$ in variety JG 14 . Whereas, effects of Tr- 1, Tr- 3, Tr- 5 and Pseudomonas fluorescens was found statistically at par (Table 2). Similarly, 100 per cent germination was also recorded with Tr- 7 . Other treatments were also found significantly effective in enhancing germination percentages in JG 24 as compared to 60 per cent in pathogen treated control and 73.33 per cent in untreated control. Whereas, differences among treatments Tr- 1 , Tr- 2, Tr- 3, Tr- 5 and $\operatorname{Tr}-6$ were found statistically at par.No seed rotting was recorded with Tr-2, Tr- 6 and Tr7 treatments in variety JG 14 and with $\mathrm{Tr}-7$ treatment in variety JG 24. However seed rotting ranges from 0 to 33.33 and 0 to 40 per cent inJG 14 and JG 24 respectively with different treatments.

There was significant reduction in seedling mortality observed with different isolates of Trichoderma spp., out of which minimum seedling mortality of 6.67 per cent was recorded with Tr- 7 followed by Tr- 2 and Tr6, Tr- 1 and Tr- 3 and Tr- 5 exhibited 20, 21.67 and 30 per cent mortality respectively which differ significantly as compared to 77.22 per cent in pathogen treated control and 50 per cent in untreated control. Similarly, in variety JG 24 minimum seedling mortality of 6.67 per cent was found with $\mathrm{Tr}-7$, followed by Tr- 2 and Tr- 6, Tr- 1 , Tr- 3 and Tr- 5 exhibited 20, 23.33, 21.67 and 28.33 per cent respectively. Other treatments also significantly reduce seedling mortality as compared to 77.78 per cent in pathogen treated control in variety JG 24 . Whereas, differences among treatments Tr- $1, \mathrm{Tr}-2$, Tr3 and Tr- 6 isolates were found statistically at par.

\section{Soil inoculation}

Data presented in the Table 3 revealed that, there was significant increase in germination percentage up to 100 per cent, recorded with Tr- 7 and Tr- 6 in variety JG 14. However, in other treatments 93.33 per cent germination recorded with Tr- 1, Tr- $2, \operatorname{Tr}-3, \mathrm{Tr}-4$ and Pseudomonas fluorescens, and followed by 86.66 per cent with Tr- 5 against 66.67 per cent in pathogen treated control. Similarly, 100 per cent germination was recorded with Tr- 7 and Tr- 5 in variety JG 24. Other treatments were only found significantly effective in enhancing germination per cent in JG 24 as compared to 60 per cent in pathogen treated control and 73.33 per cent in untreated control. Whereas differences among treatments Tr- 1, Tr- 2, Tr- 3and Tr- 4 were found statistically at par.No seed rotting was recorded with Tr- 6 and Tr- 7 treatments in JG 14and with Tr- 7 treatment in variety JG 24 . However seed rotting ranges from 0 per cent to 33.33 per cent in JG 14 and 0 to 40 per cent in JG 24 with different treatments.

Significant reduction in seedling mortality was observed with different isolates of Trichoderma spp., of which minimum seedling mortality of 6.67 per cent was recorded with Tr- 7 followed by 13.33 per cent with Tr- 6 in variety JG 14 which differ significantly as compare to 77.22 per cent in pathogen treated control and 50 per cent in untreated control. Whereas, differences among treatments Tr- 1 , Tr- 2, Tr- 3 and Tr- 5 were found at par. Similarly, in variety JG 24 minimum seedling mortality of 13.33 per cent was found with $\operatorname{Tr}-7$, followed by 20 and 
21.67 per cent in isolates Tr- 2 and Tr- $6, \operatorname{Tr}-3$ and $\operatorname{Tr}-5$ respectively. Effect of $\operatorname{Tr}-7$ was found highly significant than other treatments whereas, differences among treatments $\operatorname{Tr}-2$, Tr- 3, Tr- 6 and Pseudomonas fluorescens were found statistically at par.

Efficacy isolates of Trichoderma spp. in combination with Pseudomonas fluorescens against collar rot incidence of chickpea in Cvs JG 14 and JG 24

\section{Seed treatment}

There was significant increase in germination percentage of $93.33 \%$ found with treatment $\mathrm{Tr}-4+P$. fluorescens in variety JG 14 against 86.67 per cent when used alone with $\mathrm{Tr}-4$ isolate. In all most treatments i.e. $\operatorname{Tr}-1+P$. fluorescens, Tr- $3+P$. fluorescens and Tr- $5+$ $P$. fluorescens germination percentages decreased significantly. Whereas, in treatments Tr- $2+P$. fluorescens $(100 \%)$, Tr$6+P$. fluorescens (100\%), Tr- $7+P$. fluorescens $(100 \%)$ and $\mathrm{Tr}-8+P$. fluorescens $(86.67 \%)$ no change in germination percentage were recorded (Table 4). However, significant increased germination percentage was recorded in treatment $\mathrm{Tr}-2+P$. fluorescens and $\mathrm{Tr}-6+P$. fluorescens in variety JG 24 from 93.33 to 100 per cent. In treatments Tr- 1 $+P$. fluorescens, Tr- $3+P$. fluorescens and Tr- $5+P$. fluorescens germination percentages decreased significantly as compared to when applied alone. However, no change in germination percentage recorded with Tr- $4+P$. fluorescens $(86.67 \%)$ and Tr- 7 + P. fluorescens $(100 \%)$.

Table.1 Categorization of different isolates of Trichoderma spp. based on radial growth rate and per cent zone inhibition

\begin{tabular}{|c|c|c|c|c|c|}
\hline Crop & Isolates & $\begin{array}{c}\text { Radial } \\
\text { Growth On } 3^{\text {rd }} \\
\text { Day }(\mathrm{mm})\end{array}$ & $\begin{array}{l}\text { Per cent zone } \\
\text { Inhibition of } \\
\text { S. rolfsii }(\%)\end{array}$ & Remark & $\begin{array}{c}\text { Re-designation } \\
\text { of selected } \\
\text { Isolates }\end{array}$ \\
\hline \multirow{3}{*}{$\begin{array}{l}\text { Red } \\
\text { gram }\end{array}$} & $\mathrm{T}-1$ & 32.0 & 77.3 & \multirow{3}{*}{$\mathrm{T}-1$} & \multirow{3}{*}{$\operatorname{Tr}-1$} \\
\hline & T- 3 & 45.0 & 52.22 & & \\
\hline & T- 6 & 34.0 & 57.85 & & \\
\hline \multirow[t]{2}{*}{ Rice } & T- 2 & 32.3 & 69.11 & \multirow[b]{2}{*}{$\mathrm{T}-2$} & \multirow[b]{2}{*}{ Tr- 2} \\
\hline & $\mathrm{T}-4$ & 31.0 & 60.11 & & \\
\hline \multirow[t]{3}{*}{ Soybean } & T- 8 & 32.9 & 56.3 & \multirow{3}{*}{ T- 17} & \multirow{3}{*}{$\operatorname{Tr}-3$} \\
\hline & T- 9 & 31.0 & 56 & & \\
\hline & T- 17 & 34.0 & 61.85 & & \\
\hline \multirow[t]{2}{*}{ Sesame } & T- 13 & 27.0 & 49.82 & \multirow[b]{2}{*}{$\mathrm{T}-14$} & \multirow[b]{2}{*}{ Tr- 4} \\
\hline & $\mathrm{T}-14$ & 31.0 & 59.7 & & \\
\hline \multirow{3}{*}{$\begin{array}{l}\text { Green } \\
\text { gram }\end{array}$} & $\mathrm{T}-10$ & 32.5 & 85 & \multirow{3}{*}{ T- 10} & \multirow{3}{*}{$\operatorname{Tr}-5$} \\
\hline & $\mathrm{T}-12$ & 44.5 & 57.11 & & \\
\hline & T- 16 & 30.5 & 56.66 & & \\
\hline \multirow{2}{*}{$\begin{array}{l}\text { Black } \\
\text { gram }\end{array}$} & T- 18 & 33.5 & 55 & \multirow[b]{2}{*}{ T- 20} & \multirow[b]{2}{*}{ Tr- 6} \\
\hline & $\mathrm{T}-20$ & 32.5 & 87.41 & & \\
\hline \multirow[t]{3}{*}{ Neem } & $\mathrm{T}-11$ & 32.5 & 59.47 & \multirow{3}{*}{ T- 15} & \multirow{3}{*}{ Tr- 7} \\
\hline & T- 15 & 41.0 & 71.11 & & \\
\hline & T- 19 & 33.5 & 56.33 & & \\
\hline \multirow[t]{2}{*}{ Okra } & T- 5 & 34.5 & 55.93 & \multirow[b]{2}{*}{$\mathrm{T}-5$} & \multirow[b]{2}{*}{ Tr- 8} \\
\hline & $\mathrm{T}-7$ & 34.1 & 39.78 & & \\
\hline
\end{tabular}

Data presented in the table are average of three replications 
Table.2 Efficacy of different isolates of Trichoderma spp. and Pseudomonas fluorescens as seed treatment against collar rot incidence of chickpea in Cvs JG 14 and JG 24

\begin{tabular}{|c|c|c|c|c|c|c|}
\hline Verities & \multicolumn{3}{|l|}{ JG 14} & \multicolumn{3}{|l|}{ JG 24} \\
\hline \multirow[t]{2}{*}{ Treatment } & \multirow{2}{*}{$\begin{array}{l}\text { Germ. } \\
(\%)\end{array}$} & \multicolumn{2}{|c|}{$\begin{array}{l}\text { Percent } \\
\text { Mortality }\end{array}$} & \multirow{2}{*}{$\begin{array}{l}\text { Germ. } \\
(\%)\end{array}$} & \multicolumn{2}{|c|}{$\begin{array}{l}\text { Percent } \\
\text { Mortality }\end{array}$} \\
\hline & & $\begin{array}{l}\text { Seed } \\
\text { rot }\end{array}$ & $\begin{array}{l}\text { Seedling } \\
\text { mortality }\end{array}$ & & $\begin{array}{l}\text { Seed } \\
\text { rot }\end{array}$ & $\begin{array}{l}\text { Seedling } \\
\text { mortality }\end{array}$ \\
\hline Tr- 1 isolate & 93.33 & 6.67 & 21.67 & 93.33 & 6.67 & 23.33 \\
\hline Tr- 2 isolate & 100 & 0 & 20 & 93.33 & 6.67 & 20 \\
\hline Tr- 3 isolate & 93.33 & 6.67 & 21.67 & 93.33 & 6.67 & 21.67 \\
\hline Tr- 4 isolate & 86.67 & 13.33 & 40.00 & 86.67 & 13.33 & 36.67 \\
\hline Tr- 5 isolate & 93.33 & 6.67 & 30.00 & 93.33 & 6.67 & 28.33 \\
\hline Tr- 6 isolate & 100 & 0 & 20.00 & 93.33 & 6.67 & 20 \\
\hline Tr- 7 isolate & 100 & 0 & 6.67 & 100 & 0 & 6.67 \\
\hline Tr- 8 isolate & 86.67 & 13.33 & 31.67 & 86.67 & 13.33 & 31.67 \\
\hline Pseudomonas fluorescens & 93.33 & 6.67 & 28.33 & 86.67 & 13.33 & 23.33 \\
\hline Carbendazim + Thiram $(1: 1)$ & 86.67 & 13.33 & 36.67 & 86.67 & 13.33 & 45 \\
\hline Inoculated soil +no treatment & 66.67 & 33.33 & 72.22 & 60 & 40 & 77.78 \\
\hline Healthy soil + no treatment & 80 & 20 & 50.00 & 73.33 & 26.67 & 52.78 \\
\hline $\mathrm{SE} \mathbf{m}( \pm)$ & 0.901 & 0.901 & 1.450 & 1.425 & 1.425 & 1.473 \\
\hline CD 5\% & 2.645 & 2.645 & 4.257 & 4.184 & 4.184 & 4.326 \\
\hline
\end{tabular}

Data presented in the table are average of three replications

Table.3 Efficacy of different isolates of Trichoderma spp. and Pseudomonas fluorescens as soil inoculation against collar rot incidence of chickpea in Cvs JG 14 and JG 24

\begin{tabular}{|c|c|c|c|c|c|c|}
\hline \multirow{3}{*}{\begin{tabular}{|l} 
Verities \\
Treatment
\end{tabular}} & \multicolumn{3}{|l|}{ JG 14} & \multicolumn{3}{|l|}{ JG 24} \\
\hline & \multirow{2}{*}{$\begin{array}{l}\text { Germ. } \\
(\%)\end{array}$} & \multicolumn{2}{|c|}{$\begin{array}{l}\text { Percent } \\
\text { Mortality }\end{array}$} & \multirow{2}{*}{$\begin{array}{l}\text { Germ. } \\
(\%)\end{array}$} & \multicolumn{2}{|c|}{$\begin{array}{l}\text { Percent } \\
\text { Mortality }\end{array}$} \\
\hline & & $\begin{array}{l}\text { Seed } \\
\text { rot }\end{array}$ & $\begin{array}{l}\text { Seedling } \\
\text { mortality }\end{array}$ & & $\begin{array}{l}\text { Seed } \\
\text { rot }\end{array}$ & $\begin{array}{l}\text { Seedling } \\
\text { mortality }\end{array}$ \\
\hline Tr- 1 isolate & 93.33 & 6.67 & 21.67 & 93.33 & 6.67 & 28.33 \\
\hline $\mathrm{Tr}-2$ isolate & 93.33 & 6.67 & 20.00 & 93.33 & 6.67 & 20 \\
\hline Tr- 3 isolate & 93.33 & 6.67 & 26.67 & 93.33 & 6.67 & 21.67 \\
\hline Tr- 4 isolate & 93.33 & 6.67 & 38.33 & 86.67 & 13.33 & 36.67 \\
\hline Tr- 5 isolate & 86.67 & 13.33 & 21.67 & 93.33 & 6.67 & 28.33 \\
\hline Tr- 6 isolate & 100 & 0.00 & 13.33 & 93.33 & 6.67 & 20 \\
\hline Tr- 7 isolate & 100 & 0.00 & 6.67 & 100 & 0 & 13.33 \\
\hline Tr- 8 isolate & 80.00 & 20.00 & 33.33 & 86.67 & 13.33 & 31.67 \\
\hline Pseudomonas fluorescens & 93.33 & 6.67 & 28.33 & 86.67 & 13.33 & 23.33 \\
\hline Carbendazim + Thiram $(1: 1)$ & 80.00 & 20.00 & 39.44 & 86.67 & 13.33 & 45 \\
\hline Inoculated soil +no treatment & 66.67 & 33.33 & 72.22 & 60 & 40 & 77.78 \\
\hline Healthy soil + no treatment & 80.00 & 20.00 & 50.00 & 73.33 & 26.67 & 52.78 \\
\hline SE $\mathbf{m}( \pm)$ & 1.207 & 1.207 & 1.696 & 1.458 & 1.458 & 2.268 \\
\hline CD $5 \%$ & 3.544 & 3.544 & 4.98 & 4.28 & 4.28 & 6.658 \\
\hline
\end{tabular}

Data presented in the table are average of three replications 
Table.4 Efficacy of different isolates of Trichoderma spp. in combination with Pseudomonas fluorescens as seed treatment on per cent germination and mortality of chickpea in Cvs JG 14 and JG 24

\begin{tabular}{|c|c|c|c|c|c|c|}
\hline \multirow{3}{*}{ Treatment } & \multicolumn{3}{|l|}{ JG 14} & \multicolumn{3}{|l|}{ JG 24} \\
\hline & \multirow{2}{*}{$\begin{array}{l}\text { Germ. } \\
(\%)\end{array}$} & \multicolumn{2}{|c|}{$\begin{array}{l}\text { Percent } \\
\text { Mortality }\end{array}$} & \multirow{2}{*}{$\begin{array}{l}\text { Germ. } \\
(\%)\end{array}$} & \multicolumn{2}{|c|}{$\begin{array}{l}\text { Percent } \\
\text { Mortality }\end{array}$} \\
\hline & & $\begin{array}{l}\text { Seed } \\
\text { rot }\end{array}$ & $\begin{array}{l}\text { Seedling } \\
\text { mortality }\end{array}$ & & $\begin{array}{l}\text { Seed } \\
\text { rot }\end{array}$ & $\begin{array}{l}\text { Seedling } \\
\text { mortality }\end{array}$ \\
\hline Tr- 1 isolate & 93.33 & 6.67 & 21.67 & 93.33 & 6.67 & 23.33 \\
\hline Tr- 2 isolate & 100 & 0 & 20 & 93.33 & 6.67 & 20 \\
\hline Tr- 3 isolate & 93.33 & 6.67 & 21.67 & 93.33 & 6.67 & 21.67 \\
\hline Tr- 4 isolate & 86.67 & 13.33 & 40 & 86.67 & 13.33 & 36.67 \\
\hline Tr- 5 isolate & 93.33 & 6.67 & 30 & 93.33 & 6.67 & 28.33 \\
\hline Tr- 6 isolate & 100 & 0 & 20 & 93.33 & 6.67 & 20 \\
\hline Tr- 7 isolate & 100 & 0 & 6.67 & 100 & 0 & 6.67 \\
\hline Tr- 8 isolate & 86.67 & 13.33 & 31.67 & 86.67 & 13.33 & 31.67 \\
\hline $\begin{array}{l}\text { Tr- } 1 \text { isolate + } \\
\text { P. fluorescens }\end{array}$ & 86.67 & 13.33 & 40 & 86.67 & 13.33 & 36.67 \\
\hline $\begin{array}{l}\text { Tr- } 2 \text { isolate }+ \\
\text { P. fluorescens }\end{array}$ & 100 & 0 & 20 & 100 & 0 & 13.33 \\
\hline $\begin{array}{l}\text { Tr- } 3 \text { isolate }+ \\
\text { P. fluorescens }\end{array}$ & 80 & 20 & 50.56 & 80 & 20 & 58.83 \\
\hline $\begin{array}{l}\text { Tr- } 4 \text { isolate }+ \\
\text { P. fluorescens }\end{array}$ & 93.33 & 6.67 & 8.83 & 86.67 & 13.33 & 6.67 \\
\hline $\begin{array}{l}\text { Tr- } 5 \text { isolate }+ \\
\text { P. fluorescens }\end{array}$ & 86.67 & 13.33 & 36.67 & 86.67 & 13.33 & 38.33 \\
\hline $\begin{array}{l}\text { Tr- } 6 \text { isolate }+ \\
\text { P. fluorescens }\end{array}$ & 100 & 0 & 13.33 & 100 & 0 & 13.33 \\
\hline $\begin{array}{l}\text { Tr- } 7 \text { isolate }+ \\
\text { P. fluorescens }\end{array}$ & 100 & 0 & 6.67 & 100 & 0 & 6.67 \\
\hline $\begin{array}{l}\text { Tr- } 8 \text { isolate }+ \\
\text { P. fluorescens }\end{array}$ & 86.67 & 13.33 & 28.33 & 93.33 & 6.67 & 28.33 \\
\hline $\begin{array}{l}\text { Pseudomonasfl } \\
\text { uorescens } \\
\end{array}$ & 93.33 & 6.67 & 28.33 & 86.67 & 13.33 & 23.33 \\
\hline $\begin{array}{l}\text { Carbendazim + } \\
\text { Thiram (1:1) }\end{array}$ & 86.67 & 13.33 & 36.67 & 86.67 & 13.33 & 45 \\
\hline $\begin{array}{l}\text { Inoculated soil } \\
\text { +no treatment }\end{array}$ & 66.67 & 33.33 & 72.22 & 60 & 40 & 77.78 \\
\hline $\begin{array}{l}\text { Healthy soil }+ \\
\text { no treatment }\end{array}$ & 80 & 20 & 50 & 73.33 & 26.67 & 52.78 \\
\hline SE $m( \pm)$ & 1.083 & 1.083 & 1.533 & 1.425 & 1.425 & 1.434 \\
\hline CD 5\% & 3.106 & 3.106 & 4.397 & 4.087 & 4.087 & 4.114 \\
\hline
\end{tabular}

Data presented in the table are average of three replications 
Table.5 Efficacy of different isolates of Trichoderma spp. in combination with Pseudomonas fluorescens as soil inoculation on per cent germination and mortality of chickpea

in Cvs JG 14 and JG 24

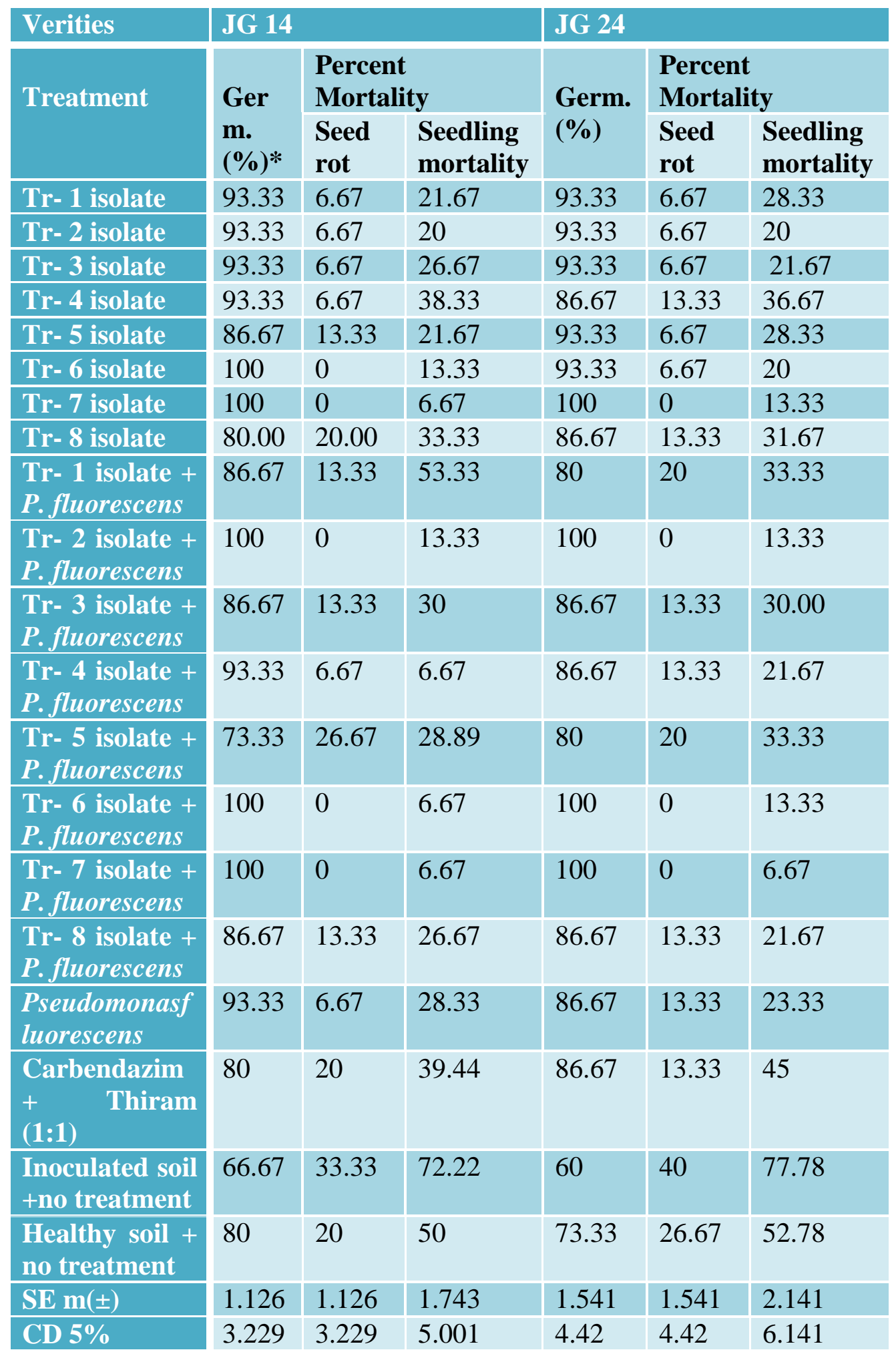

Data presented in the table are average of three replications 
Plate.1 Pure culture of best eight isolates of Trichoderma spp. from each crop
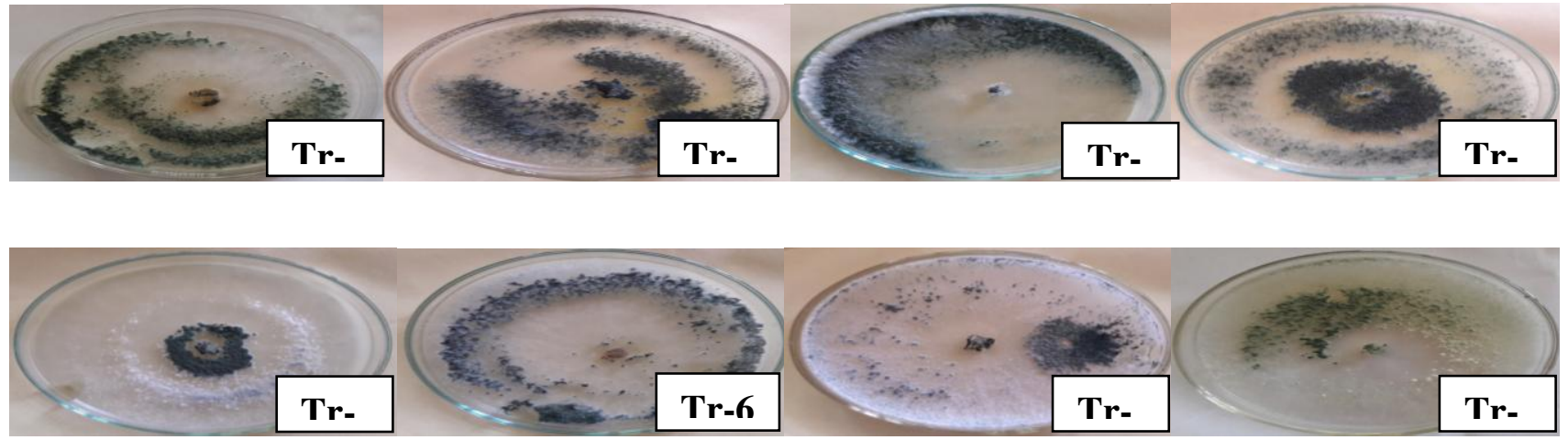

Plate.2 Bio-fficacy of different isolates of Trichoderma spp. and Pseudomonas fluorescensas seed treatment against collar rot incidence of chickpea in Cv JG 14

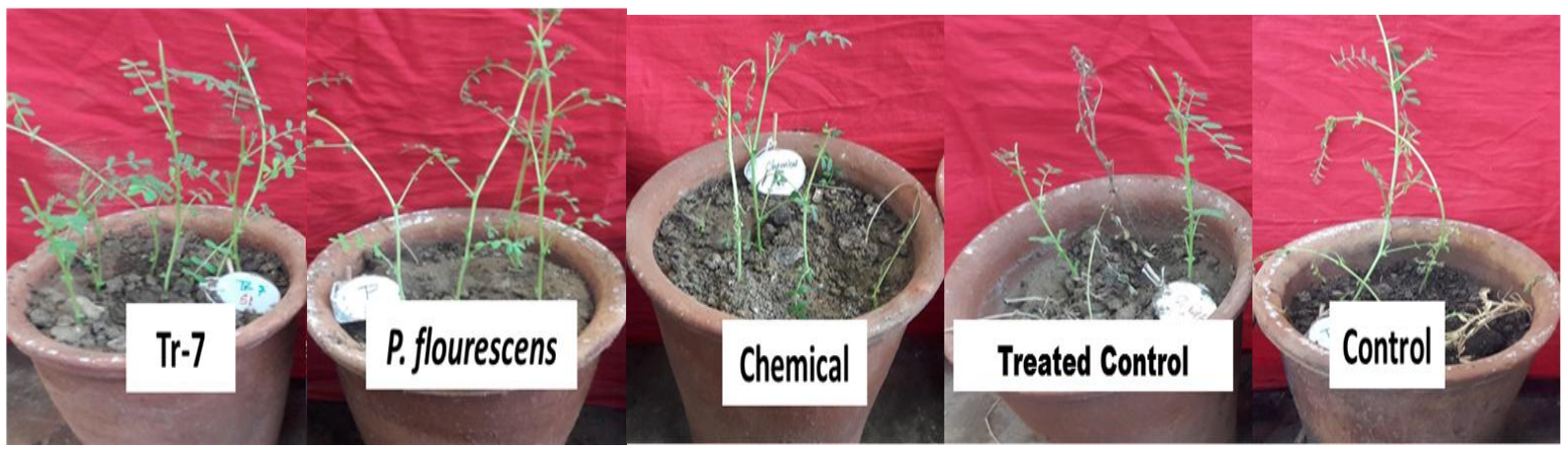

Plate.3 Bio-fficacy of different isolates of Trichoderma spp. and Pseudomonas fluorescens as soil inoculation against collar rot incidence of chickpea in Cv JG 14

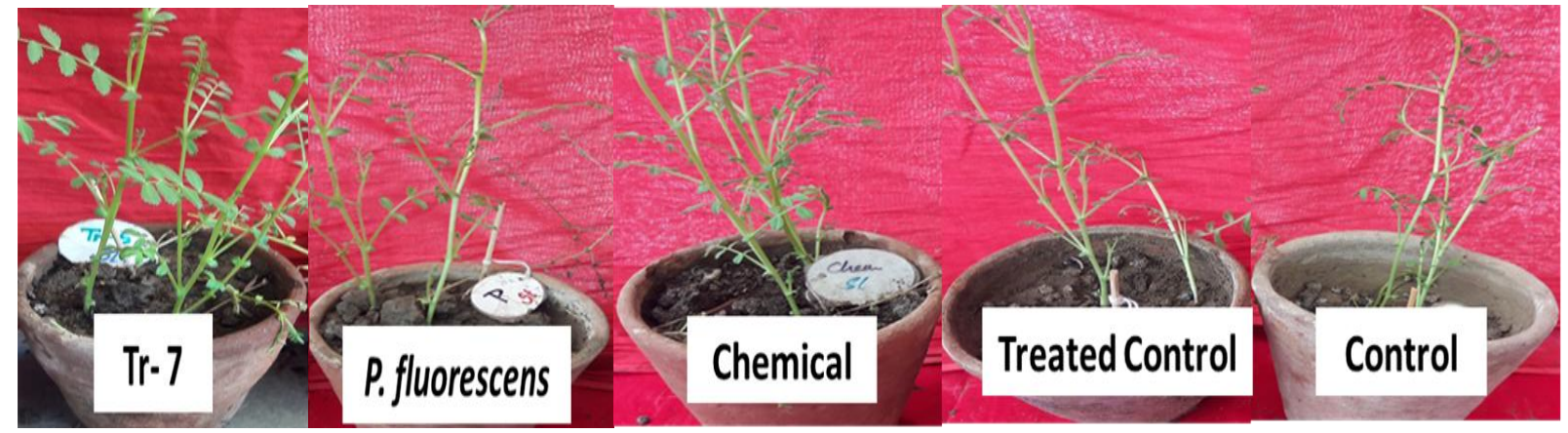

There was significant decreased in seedling mortality was recorded in most treatments i.e. Tr- $4+P$. fluorescens, Tr- $6+P$. fluorescens and Tr- $8+P$. fluorescens with $8.83,13.33$ and 28.33 per cent respectively as compared to seedling mortality when applied alone in variety JG 14 . However, increased in seedling mortality was recorded in treatments with $\mathrm{Tr}$ $1+P$. fluorescens, Tr- $3+P$. fluorescens and Tr- $5+P$. fluorescens with 40, 50.56 and 36.67 per cent respectively as compared to seedling mortality when applied alone. Whereas, effects of Tr- $2+P$. fluorescens, Tr$7+P$. fluorescens and Tr- $8+P$. fluorescens 
were found statistically at par as compared to when applied alone. Similarly, decreased in seedling mortality was recorded in treatments Tr- $2+P$. fluorescens, $\mathrm{Tr}-4+P$. fluorescens, Tr- 6+ P. fluorescens, and Tr- $8+P$. fluorescens with 13.33, 6.67, 13.33, and 28.33 per cent respectively as compared to seedling mortality when applied alone in variety JG 24.

However, significant increased in seedling mortality was recorded in treatments with $\mathrm{Tr}$ $1+P$. fluorescens (36.67\%), Tr- $3+P$. fluorescens $(58.33 \%)$ and $\mathrm{Tr}-5+P$. fluorescens (38.33\%). Whereas, differences among the treatments $\mathrm{Tr}-6+P$. fluorescens, and $\mathrm{Tr}-8+P$. fluorescens were found statisticallyat par as compared to when applied alone.

\section{Soil inoculation}

There was significant increase in germination percentage was found in treatment $\mathrm{Tr}-2+P$. fluorescens $(100 \%)$ and $\mathrm{Tr}-8+P$. fluorescens $(86.67 \%)$ in variety JG 14 against $93.33 \%$ and $80 \%$ when used alone with $\mathrm{Tr}-2$ and $\mathrm{Tr}-8$ respectively (Table 5). In all most treatments i.e. $\operatorname{Tr}-1+P$. fluorescens, $\operatorname{Tr}-3+P$. fluorescens and $\mathrm{Tr}-5+P$. fluorescens germination percentages decreased significantly. Whereas, in treatments $\operatorname{Tr}-4+$ $P$. fluorescens (93.33\%), $\mathrm{Tr}-6+P$. fluorescens $(100 \%)$ and $\mathrm{Tr}-7+P$. fluorescens (100\%)effects was found at par. However, significant increased germination percentage was recorded in treatment $\operatorname{Tr}-2+P$. fluorescens and Tr- $6+P$. fluorescens in variety JG 24 from 93.33 to 100 per cent. In treatments $\mathrm{Tr}-1+P$. fluorescens, $\mathrm{Tr}-3+P$. fluorescens and $\mathrm{Tr}-5+P$. fluorescens germination percentages decreased significantly. However, no change in germination percentage recorded with $\mathrm{Tr}-4+$ $P$. fluorescens (86.67\%), Tr- $7+P$. fluorescens $(100 \%)$ and $\mathrm{Tr}-8+P$. fluorescens
(86.67\%). Whereas, there was significant decreased in seedling mortality was recorded in most treatments i.e. Tr- $2+P$. fluorescens, Tr- $4+P$. fluorescens, Tr- 6 and Tr- $8+P$. fluorescens with 13.33, 6.67, 6.67 and 26.67 per cent respectively as compared to seedling mortality when applied alone in variety JG 14. However, significant increased in seedling mortality was recorded in treatments with $\mathrm{Tr}$ $1+P$. fluorescens and $\mathrm{Tr}-5+P$. fluorescens with 53 and 28.89 per cent respectively as compared to seedling mortality when applied alone whereas, differences among the treatments Tr- $3+P$. fluorescens and Tr- $7+$ $P$. fluorescens were found statistically at par. Similarly, decreased in seedling mortality was recorded in treatments $\mathrm{Tr}-2+P$. fluorescens, Tr- $4+P$. fluorescens, Tr- $6+P$. fluorescens, Tr- $7+P$. fluorescens and $\operatorname{Tr}-8+P$. fluorescens with 13.33, 21.67, 13.33, 6.67 per cent and 21.67 per cent respectively as compared to seedling mortality when applied alone in variety JG 24. However, significant increased in seedling mortality was recorded in treatments with $\mathrm{Tr}-3+P$. fluorescens $(30 \%)$.Whereas, effect of treatments $\mathrm{Tr}-1+$ $P$. fluorescens (33.33\%) and $\mathrm{Tr}-5+P$. fluorescens (33.33\%)were found statistically at par.

Efficacy isolates of Trichoderma spp. as seed and soil treatment against collar rot incidence of chickpea in Cvs JG 14 and JG 24

On seed treatment with different isolates of Trichoderma spp. significant reduction in seedling mortality was observed, out of which minimum seedling mortality of 6.67 per cent was recorded with Tr- 7 which differ significantly as compared to 77.22 per cent in pathogen treated control and 50 per cent in untreated control. Similarly, in variety JG 24 minimum seedling mortality of 6.67 per cent was found with Tr- 7, followed by 20 per cent in $\mathrm{Tr}-6$ and $\mathrm{Tr}-2$. Other treatments also 
significantly reduced seedling mortality as compared to 77.78 per cent in pathogen treated control (Table 4). Similar report of efficacy of Trichoderma spp. in decreasing collar rot of chickpea through seed treatment method were also reported by Biswas and Sen (2000), Dutta and Das (2002), Patibanda et al., (2002) and Jegathambigai et al., (2010).

Minimum seedling mortality of of 6.67 per cent was recorded on soil treatment with isolate Tr- 7 followed by 13.33 and 20 per cent in Tr- 2 and Tr- 6 isolates respectively in variety JG 14 as compared to 77.22 per cent in pathogen treated control and 50 per cent in untreated control in variety JG 14. Similarly, in variety JG 24 exhibited minimum seedling mortality of 13.33 per cent with $\operatorname{Tr}-7$ followed by 20 per cent in both isolates $\mathrm{Tr}-2$ and Tr- 6 as compared to 77.78 per cent in pathogen treated control (Table 5). Srivastava et al., (2010) and Montealegre et al., (2010) had also reported the similar results.

Efficacy isolates of Trichoderma spp. in combination with Pseudomonas fluorescens as seed and soil treatment against collar rot incidence of chickpea in Cvs JG 14 and JG 24

There was significant decrease in seedling mortality was recorded on seed treatmentwith most treatments i.e. $\mathrm{Tr}-4+P$. fluorescens (8.83\%), Tr- $6+P$. fluorescens and $\operatorname{Tr}-8+P$. fluorescens $(28.3 \%)$ in variety JG 14 and Tr- 2 + P. fluorescens (13.33\%), $\mathrm{Tr}-4+\mathrm{P}$. fluorescens (6.67\%), Tr- 6+ P. fluorescens $(13.33 \%)$, and $\operatorname{Tr}-8+P$. fluorescens $(28.33 \%)$ in variety JG 24 . Similar finding of synergistic effect of $P$. fluorescens with Trichoderma spp. had also been reported by Duffy et al., (1995) and Mishra et al., (2011). However, increased seedling mortality was recorded in treatments with $\operatorname{Tr}-1+P$. fluorescens (40\%), Tr- $3+P$. fluorescens $(50.56 \%)$ and $\mathrm{Tr}-5+$ P. fluorescens (36.67) in variety JG 14 and with $\mathrm{Tr}-1+P$. fluorescens (36.67\%), Tr- $3+P$. fluorescens $(58.33 \%)$ and $\mathrm{Tr}-5+P$. fluorescens $(38.33 \%)$ in variety JG 24. Similar finding of antagonistic effect of $P$. fluorescens on Trichoderma spp. on seed treatment had also been reported by Hubbard et al., (1883), Bin et al., (1991) and Mishra et al., (2011).

Similarly, on soil treatment both antagonistic and synergistic effect of $P$. fluorescens on Trichoderma spp. was found. Significant decrease in seedling mortality was recorded with Tr- $2+P$. fluorescens $(13.33 \%), \operatorname{Tr}-4+$ $P$. fluorescens $(6.67 \%)$, Tr- 6+ P. fluorescens $(6.67 \%)$ and $\mathrm{Tr}-8+$ P. fluorescens $(26.67 \%)$ in JG 14 and in Tr- $2+P$. fluorescens (13.33\%), Tr- $4+$ P. fluorescens $(21.67 \%)$, Tr- 6+ P. fluorescens (13.33\%), Tr- $7+P$. fluorescens $(6.67 \%)$ and $\mathrm{Tr}-8+P$. fluorescens $(21.67 \%)$ in JG 24. Present findings are similar to the results reported by Elad et al., (2000) and Guetsky et al., (2001). However, significant increase in seedling mortality was recorded in treatments with $\mathrm{Tr}-$ $1+P$. fluorescens and $\mathrm{Tr}-5+P$. fluorescens. Present findings are similar to the results reported by reported by Bin et al., (1991) and Mishra et al., (2011) that Pseudomonas fluorescens exhibited the antagonistic effect on Trichoderma spp. against collar rot of chickpea.

\section{Acknowledgement}

In presenting this text, I feel highly privileged to the Chairman of my Advisory Committee, Dr. S. N. Singh, Professor and Head Department of Plant Pathology and to all other Professors, Associate Professors and Assistant Professor of the Department of Plant Pathology, JNKVV, Jabalpur for their precious guidance, keen interest and inferential criticism during the course of study and preparation of the manuscript.

References 
Balasubramanian, C., Udaysoorian, P., Prabhu, C. and Kumar, G.S. 2008.Enriched compost for yield and quality enhancement in sugarcane. Journal of Eco-biology 2: pp 173-176.

Bin, L., Knudsen, G.R. and Schen, D.J. 1991. Influence of an antagonistic strain of Pseudomonas fluorescens on growth and ability of Trichoderma harzianum to colonize sclerotia of Sclerotinia sclerotiorum in soil. Phytopathology 81: pp 994-1000.

Biswas, K.K. and Sen, C. 2001. Management of stem rot of groundnut caused by Sclerotium rolfsii through Trichoderma harzianum. Indian Phytopathology 93(3): pp 290-295.

Blum, L.E.B. and Rodriguez-Kabana, R. 2004. Effect of organic amendments on sclerotial germination, mycelial growth, and Sclerotium rolfsii- induced diseases. FitopatologiaBrasileira 29(1): pp 66-74.

Curzi, M. 1931. Aleumicsidiconorenapedaleda Sclerotium observation in Italia. Alti Academia Nazionaledes Lincei Rendiconti 14: pp 233-336.

Duffy, B.K., Simons, A. and Weller, D.M. 1996. Combination of Trichoderma koeningi and Pseudomonas fluorescens for control of take-all of wheat. Phytopathology 86: pp 188-194.

Dutta, P. and Das, B.C. 2002. Management of collar rot of tomato by Trichoderma spp. and chemicals. Indian Phytopathology 92: pp 235-237.

Elad, Y., Chet, I., Boyle, P. and Hennis, Y. 1983. Parasitism of Trichoderma spp. on Rhizoctonia solani and Sclerotium rolfsii - scanning electron microscopy and fluorescence microscopy. Phytopathology 73(1): pp 85-88.

Gams, W. and Bissett, J. 2002. Morphology and identification of Trichoderma and Gliocladium: Basic Biology, Taxonomy and Genetics. pp 3-31.

Guetsky, R. 2001. Combining biocontrol agents to reduce variability of biological control.
Phytopathology 91: pp 261-267.

Hubbard, J.P., Harman, G.E. and Hadar, Y. 1983. Effect of soil borne Pseudomonas spp. on the biological control agent Trichoderma hamatum on pea seeds. Phytopathology 73: pp 655-659.

Jabbar, S., Nagaraja, A. and Nagamma, G. 2014. Efficacy of bio-pesticides against Sclerotium rolfsii Sacc. causing collar rot of chickpea. The Bioscan 9(1): pp 335339.

Jash, S. and Pan, S. 2007. Variability in antagonistic activity and root colonizing behavior of Trichoderma isolates. Journal of Tropical Agriculture, 95(2): pp 29-35.

Jegathambigai, V., Wilson, R.S. and Wijesundera, R.L.C. 2010. Effect of Trichoderma spp. on Sclerotium rolfsii, the causative agent of collar rot on Zamioculcas zamiifolia and an on farm method to mass produce Trichoderma species. Plant Pathology Journal 1: pp 19.

Kharb, R.P.S., Lather, B.P.S. and Deswal, D.P. 1994. Prediction of field emergence through heritability and genetic advance of vigour parameters. Seed Science \& Technology82: pp 461-466.

Kokub, D.F., Azam, A., Hassan, M., Ansar, M.J. and Khanum, A. 2007. Comparative growth, morphological and molecular characterization of indigenous Sclerotium rolfsii strains isolated from different locations of Pakistan. Pakistan Journal of Botany 89(5): pp 1849-1866.

Kumar, R., Maurya, S., Kumari, A., Choudhary, J., Das, B. and Kumar, S. 2012. Biocontrol potential of Trichoderma harzianum against sclerotial fungi. The Bioscan 2(3).pp 521-525.

Melo, I.S., and Faull, J.L. 2000. Parasitism of Rhizoctonia solani by strains of Trichoderma spp. ScientiaAgricolae 57(1): pp 55-59.

Mishra, D.S., Gupta, A.K., Prajapati, C.R. and Singh, U.S. 2011. Combination of fungal and bacterial antagonists for management of root rot and stem rot disease of soybean. Pakistan Journal of Botany 43: 
pp 1569-2574.

Montealegre, J., Valderrama, L., Sanchez, S., Herrera, R., Besoain, X. and Perez, L.M. 2010. Biological control of Rhizoctonia solani in tomatoes with Trichoderma harzianum mutants. Electronic Journal of Biotechnology5: pp 1-11.

Nene, Y.L., Sheila, V.K. and Sharma, S.B. 1984. A world list of chickpea $(C$. arietinum L.) and pigeon pea (Cajnus cajan (L.)) pathogens. ICRISAT Pulses Pathology Progress Report (32): pp19.

Pandey, P., Kumar, R. and Mishra, P. 2010. Studies on pathogenic behavior and carpogenic germination of sclerotia of Sclerotinia sclerotiorum causing stem rot of chickpea. Journal of Mycology and Plant Pathology 90(2): pp 192-196.

Pandey, V.S. and Chaube, H.S. 2004. Effect of fluorescent pseudomonads isolates on viability of sclerotia of Sclerotium rolfsii. Journal of Mycology and Plant Pathology 34: pp 886-888.

Patibanda, A.K., Upadhyay, J.P. and Mukhopadhyay, A.N. 2002.Efficacy of Trichoderma harzianum Rifai alone or in combination with fungicides against Sclerotium wilt of groundnut. Journal of Bio-logical Control 16: pp 57-63.

Paula, J., Teixeira, T.J., Vieira, H., Lehner, R.F., Lima, M.S., and Queiroz, R.C. 2011.Susceptibility of leguminous green manure species to Rhizoctonia solani and Sclerotium rolfsii. Summa Phytopathologica 37(4): pp 218-220.

Persoon, C.H. 1794. Neuer Veersuch einer systematischen Eintheilung der
Schwamme

(Disposition methodicafungorum). Romer's news magazine 84: pp 63-128.

Pinheiro, V.R., Lima, M.S. and Queiroz, R.C. 2010.Development of Sclerotium rolfsii sclerotia on soybean, corn, and wheat straw, under different soil temperatures and moisture contents. Pesquisa Agropecuaria Brasileira 4(3): pp 332-334.

Rudresh, D.L., Shivaprakash, M.K. and Prasad, R.D. 2005. Potential of Trichoderma spp. as bio-control agents of pathogens involved in wilt complex of chickpea (Cicer arietinum L.). Journal of Biological Control 19(2): pp 157-166.

Saccardo, P.A. 1911. Notaemycologicae. Annals Mycology 9: 249-257.

Shrivastava, S.K., Singh, S.N. and Khare, M.N. 1984. Assessment of yield losses in some promising gram cultivars due to Fusarium wilt. Indian Journal of Plant Protection 12: $125-126$.

Swathi, B., Patibanda, A.K. and Prasuna, R.P. 2015. Antagonistic Efficacy of Trichoderma spp. on Sclerotium rolfsii in vitro. IOSR Journal of Agriculture and Veterinary Science 8(7): pp 19-22

Thakur, A.K. and Norris, R.V. 1928. A biochemical study of some soil fungi with special reference to ammonia production. Journal of Indian Institute of Science 18: pp 141-160.

Upadhyay, J.P. and Mukhopadhyay, A.N. 1986. Biological control of Sclerotium rolfsii by Trichoderma harzianumin sugar beet. Tropical Pest Management 32: pp 215220.

\section{How to cite this article:}

Jhumishree Meher, Punam Kashyap, Siddharth Shankar Sonkar, S.N. Singh and Sanam Kumari. 2018. Studies on Native Isolates of Fungal and Bacterial Bio-agents against Collar Rot of Chickpea. Int.J.Curr.Microbiol.App.Sci. 7(01): 226-238. doi: https://doi.org/10.20546/ijcmas.2018.701.025 